\title{
Stephen Cranney
}

\section{Criminal Stain on a White Collar - A Critical Analysis of Proposed Changes to Directors' Liabilities}

\author{
Submitted for the LLB (Honours) Degree
}

Faculty of Law

Victoria University of Wellington

2013 


\section{Contents}

I INTRODUCTION

II DECISIONS UNDER CURRENT LAW ................................................................... 4

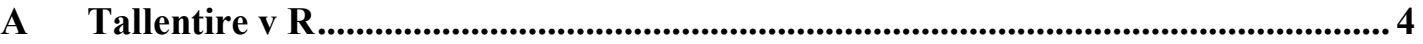

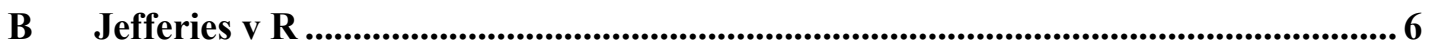

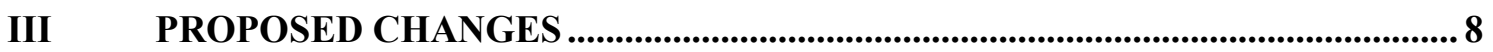

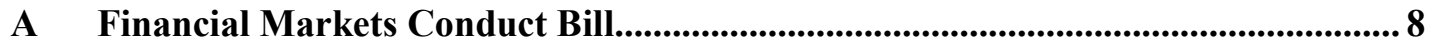

B Companies and Limited Partnerships Amendment Bill........................................ 10

IV POTENTIAL EFFECTS OF THE PROPOSED CHANGES .............................. 11

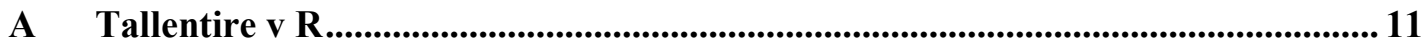

$1 \quad$ Financial Markets Conduct Bill ..................................................................... 11

2 Companies and Limited Partnerships Amendment Bill ........................... 12

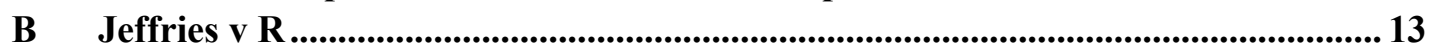

$1 \quad$ Financial Markets Conduct Bill ......................................................................... 13

2 Companies and Limited Partnerships Amendment Bill ........................ 18

V CURRENT LAW VS. PROPOSED CHANGES - DISCUSSION ........................ 22

A Securities Act 1978 and Financial Markets Conduct Bill....................................... 22

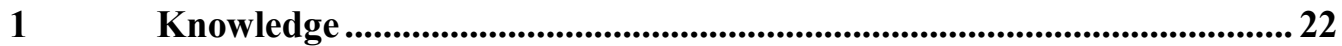

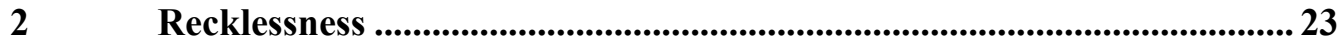

B Companies and Limited Partnerships Amendment Bill......................................... 24

1 Section 131........................................................................................................... 24

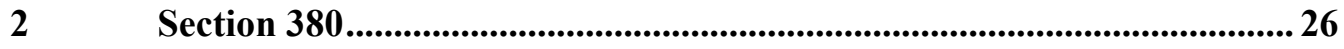

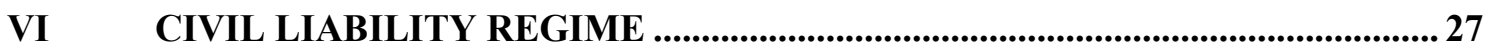

A Civil liability vs. criminal liability .................................................................................. 27

B Problems within the civil liability regime ......................................................................... 29

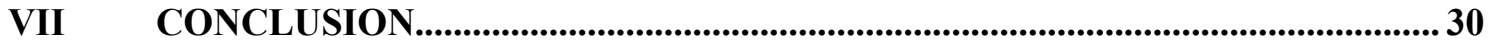

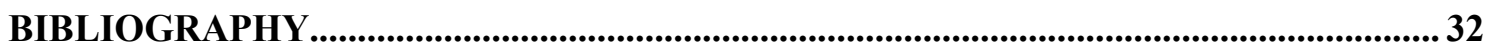




\section{Abstract:}

The recent finance company collapses have highlighted the need for improved director accountability. However where is the appropriate point to draw the line, which if crossed, imposes criminal liability? The Financial Markets Conduct Bill and the Companies and Limited Partnerships Amendment Bill both attempt to redefine when criminal liability will attach to directors. By assessing the proposed changes in the light of two recent cases, it can be seen that under the proposed changes, directors have the potential to be found criminally liable for less than dishonest behaviour. This raises the issue of whether criminal liability is appropriate in regards to directors' actions, or whether a civil liability scheme would be more appropriate. This paper looks at the current law and the proposed changes to directors' liability, and by considering the situations of two failed finance companies, attempts to draw conclusions as to the effects of such changes.

\section{Keywords:}

Director's Duties, Criminal Liability, Securities.

\section{Introduction}

Two Bills in Parliament have the potential to greatly change the criminal system in which liability for directors is determined. This begs the question of whether such changes will be an improvement on the existing regime. It also raises the inquiry of whether such Bills will achieve the purposes which they set out to accomplish. This paper attempts to find answers to these questions by looking at the current law, as interpreted by two recent cases and the potential effects of the proposed changes.

The Financial Markets Conduct Bill (FMC Bill) and the Companies and Limited Partnerships Amendment Bill (CLPA Bill) look to radically change the current criminal framework. The effects of these Bills can be determined by assessing them in the light of actual scenarios. Tallentire $v R^{l}$ (Tallentire) and Jeffries $v R^{2}$ (Jefferies) are both cases decided under the current law, both involving criminal liability for finance company directors. They show the current system's purpose, and also the problems associated with it. How would these cases have been decided if the proposed changes had been in force at the relevant time? An answer to whether the changes will be beneficial to directors,

${ }^{1}$ Tallentire $v R$ [2012] NZCA 610, [2013] 1 NZLR 548.

${ }^{2}$ William Patrick Jeffries $v$ R [2013] NZCA 188. 
whether problems will be solved or whether the changes will create further issues and concerns for directors, can be determined from this analysis.

This paper will look at the Tallentire and Jeffries decisions, and then summarise the proposed changes to the law regarding company directors' liabilities. By applying the proposed changes to these two factual situations, a view can be gained as to the likely outcome and effects of the two Bills. Through looking closely at the proposed changes and their potential effects, this paper will attempt to draw conclusions on questions asked above.

\section{Decisions under current law}

\section{A Tallentire v $R$}

This case concerned the prosecution of three directors of Capital + Merchant Finance Limited (Capital) after that company's collapse. Each director was found guilty of theft by a person in a special relationship under s 220 of the Crime Act $1961 .^{3}$

Capital was a finance company which made loans for property development. It financed these loans by borrowing funds from the public, and in order to do this, was obliged to appoint a trustee. ${ }^{4}$ The collection and use of the funds was governed by a debenture trust deed. Clause 6(2) of the trust deed stated that Capital was restricted from entering into any related party transaction without the prior consent of the trustee, unless the transaction was in the ordinary course of business. Prior to the collapse of Capital, the company under took three relevant transactions, described in the case as Numeria 1 and the Clyde transactions.

The complex transactions served the purpose of personally benefiting the three directors. All three transactions were related party transactions under the trust deed, for which the consent of the trustee was not sought.

\footnotetext{
${ }^{3} R v$ Douglas [2012] NZHC 1746.

${ }^{4}$ Securities Act 1978, s 33(2).
} 
The three directors, Douglas, Nichols and Tallentire were charged under s 220 of the Crimes Act 1961. This section applies to any person who has control of property on terms that the person knows requires them to deal with the property in accordance with the requirements of any person. ${ }^{5}$ It states that every person to whom the section applies commits theft if they intentionally deal with the property otherwise than in accordance with those requirements. ${ }^{6}$ This was the first time that finance company directors had faced s 220 charges arising from alleged breaches of trust deed covenants. ${ }^{7}$

Wylie $\mathrm{J}$ in the High Court decision set out the elements of the offence as follows: ${ }^{8}$

(a) Did the accused have control over property?

(b) Was the property in the control of the accused, in circumstances that required him to deal with the property, or any proceeds arising from the property, in accordance with the requirements of any other person?

(c) Did the accused know of those circumstances? And,

(d) Did the accused intentionally deal with the property, or any proceeds of the property, otherwise than in accordance with those requirements?

Messrs Douglas and Nichols were held to have control over the property in regards to both the Numeria 1 transaction ${ }^{9}$ and the Clyde transactions. ${ }^{10}$ Mr Tallentire was only held to have control over the property in regards to the Clyde transactions. ${ }^{11}$ The trust deed contained restrictions on how investor funds could be used, and because of this, the

\footnotetext{
${ }^{5}$ Crimes Act 1961, s 220(1).

${ }^{6}$ Crimes Act 1961, s 220(2).

${ }^{7}$ Tallentire $v R$, above $\mathrm{n} 1$, at [3].

${ }^{8} R v$ Douglas, above n 3, at [149].

${ }^{9}$ Tallentire $v R$, above $\mathrm{n} 1$, at [83].

${ }^{10}$ At [104].

${ }^{11}$ At [83], [104] and [120].
} 
second element was satisfied. ${ }^{12}$ It was conceded that Messrs Douglas and Nicholls were well aware of the related party transaction restrictions. ${ }^{13}$ There was also sufficient evidence to show Mr Tallentire knew of the relevant requirements. ${ }^{14}$

The intention element of the fourth requirement was held to mean that the Crown had to prove intention to enter into the transaction and that the accused intended to breach the relevant requirement. ${ }^{15}$ Stevens $\mathrm{J}$ in the Court of Appeal upheld the decisions of Wylie J; finding that the directors did in fact intend to breach the requirements of the trust deed, such transactions were not in the ordinary course of business and that resultantly, they were guilty under s $220 .^{16}$

Having control of investor funds, whilst knowing you must use the funds in accordance with a trust deed, and intentionally breaching a trust deed requirement was established as constituting a criminal offence under s 220. The Crown did not need to prove any dishonesty. ${ }^{17}$

\section{B Jefferies $v \boldsymbol{R}$}

This case concerned the prosecution of the directors of the failed finance company, Lombard Finance and Investments Limited (Lombard). The directors were prosecuted under s 58 of the Securities Act 1978 for distributing a prospectus and advertisements containing untrue statements.

Due to difficult economic conditions, notably the failure of a number of other finance companies, Lombard was experiencing serious liquidity issues. The company had been experiencing a downward trend in its cash position, relying on loan managers' assurances

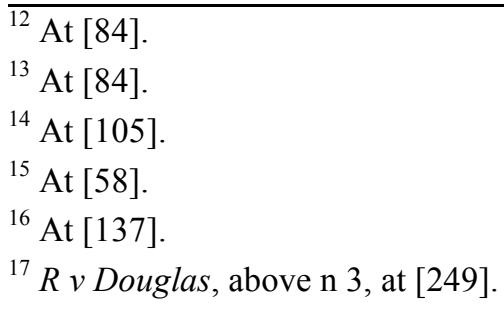


that although loan repayments were delayed, they were not irrecoverable. The directors were of the view that despite the known liquidity pressures the company was facing, they could nevertheless continue raising funds from the public. The way in which they did this was by issuing an amended prospectus and investment statement.

Section 58(3) states that where a registered prospectus that includes an untrue statement is distributed, every person who signed the prospectus commits an offence. ${ }^{18}$ Section 58(1) is a similar charge; where an advertisement for securities is distributed containing an untrue statement, and the issuer is a body, all directors of the body at the time of distribution commit an offence. ${ }^{19}$ The charge is a strict liability offence; the Crown is not required to prove any criminal intent on the part of those charged. ${ }^{20} \mathrm{~A}$ statement in a registered prospectus or in an advertisement can be deemed to be untrue if there is a material omission. ${ }^{21}$ In both the amended prospectus and investment statement that were issued, information regarding the liquidity problems was not sufficiently included. The court accepted that such an omission of liquidity concerns in the offer documents was material to investors and that without such information, the documents were misleading and untrue for the purposes of the Securities Act. ${ }^{22}$

A statutory defence to a charge under s 58 is that the person has reasonable grounds to believe, and did believe, up to the time of the distribution, that the statement in the offer document was true. ${ }^{23}$ Here, the defendants argued that they thought the combined effect of the statements in the offer documents rendered the statements true in respect to the company's liquidity. The Court of Appeal held that although the directors did believe that the amended offer documents were true despite the omitted information, such a belief was not held on objectively reasonable grounds. ${ }^{24}$ The view that monitoring the accuracy of loan repayments was a matter in which investors can rely on the directors' judgment

\footnotetext{
${ }^{18}$ Securities Act 1978, s 58(3).

${ }^{19}$ Securities Act 1978, s 58(1).

${ }^{20}$ William Patrick Jeffries $v R$, above, $\mathrm{n} 2$, at [20].

${ }^{21}$ Securities Act 1978, s 55(a)(ii).

${ }^{22}$ William Patrick Jeffries $v$, above $\mathrm{n} 2$, at [171].

${ }^{23}$ Securities Act 1978, ss 58(2) and 58(4).

${ }^{24}$ William Patrick Jeffries $v R$, above n 2, at [189]-[191].
} 
for, was unreasonable. This could therefore not provide a reasonable basis for the directors to believe the offer documents were true. ${ }^{25}$

An appeal of the decision has been lodged with the Supreme Court, based on similar alleged errors of law that were argued in the Court of Appeal. ${ }^{26}$ It remains possible that the guilty verdicts could be overturned. Currently however, omitting information relating to known material liquidity pressures on a company in disclosure documents constitutes an offence under s 58(3).

\section{Proposed Changes}

\section{A Financial Markets Conduct Bill}

Currently proceeding through Parliament is a Bill which aims to reform the regulation of New Zealand's financial markets. The Bill would repeal a number of pieces of securities legislation and replace them with a unified code. ${ }^{27}$

Amongst the reforms the FMC Bill aims to enact are a number of changes to liability, which are particularly relevant to finance company directors. The Bill repeals the current prospectus/investment statement regime and instead requires that a product disclosure statement (PDS) be prepared when regulated offers are made to potential investors, and further material disclosures must be made on a register of securities. ${ }^{28}$ An offeror must not offer or continue to offer financial products under a regulated offer if there is a

\footnotetext{
${ }^{25}$ At [189].

26 David Farrar "The Lombard appeal to the Supreme Court" (4 July 2013) KiwiBlog $<$ www.kiwiblog.co.nz/wp-content/uploads/2013/07/Lombard-Appln-Leave-to-Appeal-SC-2-July2013.pdf $>$.

27 John McSoriley "Bills Digest No 1963" (03 April 2012) New Zealand Parliament $<$ http://www.parliament.nz/en-nz/pb/legislation/bills/digests/50PLLaw19631/financial-markets-conductbill-2011-bills-digest-no-1963>.

${ }^{28}$ Financial Markets Conduct Bill 2011 (342-2), cl 35.
} 
statement or omission in the PDS or the register entry that is false or misleading or is likely to mislead. ${ }^{29}$

Under the Bill, if an offeror offers a financial product under a regulated offer, which contains an omission which is materially adverse from the point of view of an investor, and the offeror does this with knowledge or recklessness as to whether such an omission is materially adverse, then that offeror commits a criminal offence. ${ }^{30}$ In addition, the offeror's directors will criminally liable if the offer takes place with the directors' consent and the directors know or are reckless as to whether the omission is materially adverse from the perspective of an investor. ${ }^{31}$ The Bill repeals s 58 of the Securities Act 1978 replaces it with these offences, which require knowledge or recklessness.

The FMC Bill also sets out a civil liability scheme for particular contraventions of the Bill, empowering civil liability orders where there are breaches of 'civil liability provisions'. Disclosure obligations are just one of a list of provisions that can attract civil liability if breached, also including fair dealing, governance, unsolicited offers, licensing and financial reporting provisions. ${ }^{32}$ Liabilities for contraventions are imposed on the issuer and also on persons "involved in a contravention." 33 In the case of defective disclosures, if an offeror has contravened this obligation, then every director of the offeror is also deemed to have contravened the defective disclosure provision. ${ }^{34}$ However the Bill provides a number of defences for contravention of civil liability provisions, notably a defence will be available for defective disclosure if a person proves they made all reasonable enquiries and after doing so, believed on reasonable grounds that there was no omission from the disclosure document or register entry. ${ }^{35}$

\footnotetext{
${ }^{29}$ Financial Markets Conduct Bill 2011 (342-2), cl 65.

${ }^{30}$ Financial Markets Conduct Bill 2011 (342-2), cl 488(1).

${ }^{31}$ Financial Markets Conduct Bill 2011 (342-2), cl 488(1A).

${ }^{32}$ Financial Markets Conduct Bill 2011 (342-2), cl 467.

${ }^{33}$ Financial Markets Conduct Bill 2011 (342-2), cl 466.

${ }^{34}$ Financial Markets Conduct Bill 2011 (342-2), cl 509A.

${ }^{35}$ Financial Markets Conduct Bill 2011 (342-2), cl 482B(2).
} 
Under the civil liability scheme, the court can make a declaration of contravention, which enables an applicant to bring an action for compensation. ${ }^{36}$ Also, the court may order pecuniary penalty orders, a payment made to the Crown, if the court is satisfied that a person has contravened or been involved in a contravention of a civil liability provision. ${ }^{37}$ Notably, the court can make a pecuniary penalty order against a director if defective disclosure by an offeror occurs. ${ }^{38}$

The Bill does not limit or diminish any liability under the Crimes Act $1961 .{ }^{39}$ It therefore remains open that s 220 will be available as an alternative source of liability against directors who deal with publically raised funds in breach of their trust deed.

\section{B Companies and Limited Partnerships Amendment Bill}

The CLPA Bill proposes amendments to the Companies Act 1993 and the Limited Partnerships Act 2008 for the purpose of enhancing rules relating to companies and limited partnerships' governance, registration and more relevantly, criminal liability. ${ }^{40}$

Two directors' duties are relevant here, firstly the director's duty to act in good faith and in the best interests of the company. ${ }^{41}$ What is meant by good faith is that the director must act honestly; doing what he or she subjectively believes is in the best interest of the company. ${ }^{42}$ Secondly, the Companies Act sets out that a director must not agree, cause or allow the business of a company to be carried on in a manner likely to create substantial

\footnotetext{
${ }^{36}$ Financial Markets Conduct Bill 2011 (342-2), cl 469.

${ }^{37}$ Financial Markets Conduct Bill 2011 (342-2), cl 471.

${ }^{38}$ Financial Markets Conduct Bill 2011 (342-2), cl 471(5).

${ }^{39}$ Financial Markets Conduct Bill 2011 (342-2), cl 516.

${ }^{40}$ Supplementary Order Paper 2013 (249) Companies and Limited Partnerships Amendment Bill (344-2), Commentary.

${ }^{41}$ Companies Act 1993, s 131.

${ }^{42}$ G Walker and others Commercial Applications of Company Law in New Zealand (3rd ed, CCH, Auckland, 2009) at [1403].
} 
risk of serious loss to the company's creditors. ${ }^{43}$ This section's objective is the protection of creditors. Both duties are currently owed only to the company. ${ }^{44}$

The CLPA Bill proposes criminalisation of elements of these two directors' duties. Under the Bill's Supplementary Order Paper (SOP), if a director acts in bad faith towards the company, believes the conduct is not in the best interests of the company and knows or is reckless as to whether the conduct will cause serious loss to the company or benefit to a person who is not the company, then the director commits a criminal offence. ${ }^{45}$

The SOP also amends s 380 of the Companies Act 1993 to include an offence based on the reckless trading provision, stating if a director agrees, causes or allows the business of the company to be carried on in a manner that causes serious loss to the company's creditors, the director knows that a serious loss will be suffered as a result of business being carried on in that manner and the creditors concerned do not give prior consent to carrying on the business in that manner then the director commits a criminal offence. ${ }^{46}$

\section{Potential effects of the proposed changes}

\section{A Tallentire v $R$}

\section{$1 \quad$ Financial Markets Conduct Bill}

There would not likely be any change to the actions available against the directors of Capital under the proposed changes in the FMC Bill. This is because Tallentire did not

\footnotetext{
${ }^{43}$ Companies Act 1993, s 135.

${ }^{44}$ Walker and others, above $\mathrm{n}$ 42, at [1205].

${ }^{45}$ Supplementary Order Paper 2013 (249) Companies and Limited Partnerships Amendment Bill (344-2), cl 4.

${ }^{46}$ Supplementary Order Paper 2013 (249) Companies and Limited Partnerships Amendment Bill (344-2), cl 4AAB.
} 
contain any non-disclosure issue and also contained no likely breach of the fair trading provisions or any other provisions of the FMC Bill.

\section{Companies and Limited Partnerships Amendment Bill}

As stated, the CLPA Bill criminalises s 131 of the Companies Act 1993. In regards to the duty itself, a director must act in good faith and in what the director believes to be the best interests of the company. Acting in good faith means acting honestly and it is what the director subjectively thinks is in the best interests of the company that is relevant. ${ }^{47}$ However, the court has stated that this subjective believe must be genuinely held. ${ }^{48}$

The directors of Capital intentionally breached the trust deed they were bound by. They did not do this for the best interests of the company, but in the Numeria 1 transaction they did it for the purpose of allowing their parent company to record a capital gain, and distribute that capital gain to trusts associated to the directors. ${ }^{49}$ In the Clyde transactions, the purpose was to transfer control from Messrs Nichols and Douglas to Mr Tallentire. ${ }^{50}$ The reasons they undertook these transactions were for personal gain.

By undertaking transactions for purely personal benefit, the directors would likely have breached their duty owed to the company to act in good faith and in the best interests of the company. However to be criminally liable for such a breach, the action of the director must be done in bad faith towards the company, with belief it is not in the best interests of the company and knowing or being reckless as to whether the conduct will cause a serious loss to the company or benefit a person who is not the company. ${ }^{51}$

\footnotetext{
${ }^{47}$ Walker and others, above $\mathrm{n} 42$, at [1403].

${ }^{48}$ Robb v Sojourner [2007] NZCA 493.

${ }^{49} R v$ Tallentire, above $\mathrm{n} 1$, at [19]-[20].

${ }^{50}$ At [26].

${ }^{51}$ Supplementary Order Paper 2013 (249) Companies and Limited Partnerships Amendment Bill (344-2), cl 4.
} 
The directors likely undertook bad faith behavior. They all knew of the trust deed requirements and intentionally breached them, ${ }^{52}$ which was arguably dishonest. The directors also would have known that their actions would benefit persons who were not the company, namely the personal benefits the directors themselves gained through distributions to associated trusts and the transfer of control. In regards to whether the director believed the conduct was not in the best interests of the company, this subjective belief must be reasonably held. ${ }^{53}$ It is unlikely the directors would be able to argue they genuinely believed that breaching the trust deed for personal gain was in the best interest of the company. Resultantly it is very possible that the directors of Capital would be found criminally liable for the breach of duty.

\section{B Jeffries $v \boldsymbol{R}$}

\section{$1 \quad$ Financial Markets Conduct Bill}

Under the proposed changes in the FMC Bill, Lombard would be an "issuer" for the purposes of the FMC Bill. ${ }^{54}$ It would be issuing financial products ${ }^{55}$ which would require disclosure. ${ }^{56}$ An offer would be a regulated offer ${ }^{57}$ and would require a PDS and register disclosures. $^{58}$

As stated, an offeror must not offer or continue to offer a regulated financial product if there is an omission in the PDS or the register entry that is materially adverse from the point of view of an investor. ${ }^{59}$ If an offeror does make such an omission, then a director of the offeror will be criminally liable, provided the offer was made with the director's

\footnotetext{
${ }^{52}$ Tallentire $v R$, above $\mathrm{n} 1$, at [84].

${ }^{53}$ Robb v Sojourner, above n 48.

${ }^{54}$ Financial Markets Conduct Bill (342-2), cl 10.

${ }^{55}$ Financial Markets Conduct Bill (342-2), cl 7.

${ }^{56}$ Financial Markets Conduct Bill (342-2), cl 27.

${ }^{57}$ Financial Markets Conduct Bill (342-2), cl 29.

${ }^{58}$ Financial Markets Conduct Bill (342-2), cl 35.

${ }^{59}$ Financial Markets Conduct Bill (342-2), cl 65.
} 
authority and the director knew or was reckless as to whether such an omission would be materially adverse from an investor's perspective. ${ }^{60}$

The directors of Lombard distributed a prospectus and investment statement containing omissions as to material liquidity problems the company was suffering from. Notably, the lack of reliable forecasts about timing of repayments, the reduction of cash in hand and the omission of references to directors' concerns about the liquidity problems created a misleading impression as to the company's financial situation. The High Court found that investors would have assessed the risk of investing in Lombard's debenture stock differently if they had been aware of the issues regarding Lombard's liquidity. ${ }^{61}$ It was also stated that the directors believed that statements addressing the company's liquidity were true at the time the prospectus was issued. Their view was that the loan managers had legitimate explanations for the non-compliance of repayment projections and thought that the monitoring of the accuracy of the loan repayment projections was something potential investors could trust the directors' judgment for. ${ }^{62}$

In regards to the FMC Bill, in the writer's view it would be very difficult on the evidence to conclude that the directors knew that the omission of information regarding the liquidity problems would be materially adverse from the point of view of an investor. The directors knew of the liquidity issues and omitted that information. ${ }^{63}$ However this information was omitted because they subjectively thought that they could rely on the loan managers' assurances as to late repayments and investors could trust the director's judgment on the liquidity concerns. ${ }^{64}$ The directors' thoughts about the liquidity of the firm were reflected in an email from the Chairman to another director, stating that in regards to liquidity, "we are sailing very close to the wind,"65 and further in the Board meeting approving the amended prospectus, where the Chairman reiterated the Board's

\footnotetext{
${ }^{60}$ Financial Markets Conduct Bill (342-2), cl 488(1A).

${ }^{61} R v$ Graham [2012] NZHC 265 at [105].

${ }^{62}$ At [125]-[126].

${ }^{63}$ William Patrick Jeffries $v$, above $\mathrm{n}$ 2, at [195].

${ }^{64} R v$ Graham, above $\mathrm{n} 61$, at [125]-[126].

${ }^{65}$ William Patrick Jeffries $v R$, above $\mathrm{n} 2$, at [49].
} 
support for management's assurances. ${ }^{66}$ The knowledge that the Judge accepted was that they considered the statements addressing the liquidity of the company to be true despite the omissions identified. ${ }^{67}$ If they believed that the comments about liquidity were true, something they were to be trusted with and that repayments would eventuate because of the loan manager's assurances, then it is highly unlikely that the prosecution would be able to prove beyond reasonable doubt that they also believed that not including this information would be materially detrimental to a potential investor. They relied on assurances and thought the information would be immaterial to investors; this is why the information was omitted. It is highly unlikely to conclude from this evidence that the directors would be found to have known that there was an omission in the disclosures which would be materially adverse from the point of view of an investor.

Knowledge is not the only possible way to be found guilty for the offence under the FMC Bill. If a director is reckless as to whether there is an omission in the disclosures which is materially adverse from the view point of an investor then the director will be guilty. The test for recklessness is: ${ }^{68}$

"A person is reckless if, (a) knowing that there is a risk that an event may result from his conduct or that a circumstance may exist, he takes that risk; and (b) it is unreasonable for him to take it having regard to the degree and nature of the risk he knows to be present."

This is the "subjective reckless" test, and it is the general rule in New Zealand that recklessness be given its subjective meaning. ${ }^{69}$

The question that needs to be asked in regards to the Lombard directors would be: did they know that there was a risk that omitting information from the disclosures that would

\footnotetext{
${ }^{66}$ At [52].

${ }^{67}$ At [188].

${ }^{68} R v$ Stephenson [1979] QB 695 (CA).

${ }^{69} R v$ Tipple CA217/05, 22 December 2005.
} 
be materially adverse from the point of view of an investor and was the risk of making such an omission reasonable to take?

It can be argued that the directors must have been aware that there was a risk involved with not including the liquidity information, and the risk that omitting that information could been seen as materially adverse in the eyes of investors. This is evident in an email sent from the Chairman of the Board to another director, stating: ${ }^{70}$

\begin{abstract}
"Some of our exposures are difficult and dependent on a number of positive events occurring. If they do not, or there are delays, we run the risk of running out of cash... I would not want to be a party to any capital raising which misrepresents the true position"
\end{abstract}

In appreciating the risk of running out of cash, the directors also turned their minds to the issue of misrepresenting information to investors. If a director is aware of the risk of misrepresenting liquidity information, then it follows that that they are also aware that if such a misrepresentation is made, recipients of the incomplete information will be to some extent deceived. Misrepresentation has consequences, and having knowledge of a risk of misrepresentation would arguably also imply knowledge of the risk of consequences associated with such a misrepresentation. Due to an acknowledgement of the risk of misrepresentation, it can be said that the directors must have, to some extent, been aware that such a misrepresentation could lead to a materially adverse result from the point of view of an investor.

The arguments of whether it was reasonable to take the risk of omitting the information are finely balanced. On one side, it is not a court's position to be second guessing directors' decision-making, and the court should arguably be conservative when it comes to deciding whether commercial risks are reasonable or not. The long title of the Companies Act 1993 specifically allows directors a wide discretion in matters of business

${ }^{70}$ William Patrick Jeffries $v$, above $\mathrm{n} 2$, at [49]. 
judgment. ${ }^{71}$ However, as no business judgment rule operates in New Zealand, there is no rule or presumption that absolves liability for business decisions made in good faith. ${ }^{72}$ This leaves the question of reasonableness wholly in the hands of the court.

It has been held that directors should not be penalised simply for taking risks, only those which are illegitimate. ${ }^{73}$ In addressing whether a business risk is illegitimate, the court weighs up a number of relevant factors, including whether the conduct was in accordance with orthodox commercial practice, how serious the risks were in the particular context and whether creditors had full notice of risks being taken with their funds. ${ }^{74}$ It is very possible for a court to say that taking the risk of not including the information was a reasonable thing to do; taking into account the fact that the directors believed the liquidity position would improve in the future and that they were in a much better position to judge the liquidity position of their company. An objective director in the same position may have very well made the same decision.

Conversely however, the Court of Appeal stated that believing the statements to be true despite the omission was unreasonable. ${ }^{75}$ If believing the statements are true is unreasonable, then it is arguable that the risk associated with omitting the information is also unreasonable. Factors the court could look at in assessing reasonableness would be similar to ones the Court of Appeal did, namely reliance on managers, professional advisors and that the directors could be trusted to make decisions on liquidity matters. The Court held that these were unreasonable. ${ }^{76}$ If these arguments were the ones used to show the risk was reasonable, they would fail, leading to the possible result that omitting liquidity information would be an unreasonable risk.

\footnotetext{
${ }^{71}$ See Companies Act 1993 Long Title, para (d).

$72 \mathrm{~J}$ Farrar and others Company and Securities Law in New Zealand (Thompson Brookers, Wellington, 2008) at $\operatorname{ch} 15.7$.

73 South Pacific Shipping Limited (in Liquidation), Re; Traveller \& Anor v Löwer (2004) 9 NZCLC 263,570 .

${ }^{74}$ At [125].

${ }^{75}$ William Patrick Jeffries $v$, above n 2, at [198].

${ }^{76}$ William Patrick Jeffries $v$, above n 2, at [189].
} 
The prosecution would have to prove beyond reasonable doubt that it was unreasonable to take the risk of omitting the material information, a difficult thing to prove. Because the arguments seem to be so finely balanced, it does not seem likely the Crown would be able to do this, therefore making it likely that the directors would be not guilty under the reckless element.

The directors however would not be without consequence for their omission. As the offeror would have contravened $\mathrm{cl} 65$ by omitting information that would be materially adverse to a potential investor, it would have contravened a civil liability provision. ${ }^{77}$ As directors of the offeror, they are treated as contravening defective disclosure requirements if the offeror does. ${ }^{78}$ This would mean all the directors would prima facie have contravened cl 65 and be subject to civil liability orders. The court could make a declaration of the contravention, ${ }^{79}$ thereby enabling an aggrieved investor to bring an action for compensation, and it could make a pecuniary penalty order. ${ }^{80}$ The director would have a number of defences available, but these would not likely be satisfied. The defences depend on reasonable reliance ${ }^{81}$ or belief on reasonable grounds there was no omission. ${ }^{82}$ The Court of Appeal specifically stated reliance and belief in the case were not reasonable. ${ }^{83}$ Therefore, although possibly not criminally liable, the directors would likely have civil liability imposed upon them for the omission of relevant information.

\section{Companies and Limited Partnerships Amendment Bill}

The CPLA Bill would criminalise the director's duty to act in good faith and in the best interests of the company. Based on case law that has interpreted the s 131 duty, what is meant by "good faith" is that the director must act honestly, a subjective test looking at

\footnotetext{
${ }^{77}$ Financial Markets Conduct Bill (342-2), cl 467(b).

${ }^{78}$ Financial Markets Conduct Bill (342-2), cl 509A.

${ }^{79}$ Financial Markets Conduct Bill (342-2), cl 468.

${ }^{80}$ Financial Markets Conduct Bill (342-2), cls 477 and 471.

${ }^{81}$ Financial Markets Conduct Bill (342-2), cl 482A.

${ }^{82}$ Financial Markets Conduct Bill (342-2), cl 482B.

${ }^{83}$ William Patrick Jeffries $v$, above n 2, at [197]-[198].
} 
what the director thinks will be in the best interest of the company. ${ }^{84} \mathrm{New}$ Zealand requires that beliefs that underpin the decisions must be reasonably held, introducing an objective element. $^{85}$

For the criminal provision to apply the prosecution must establish bad faith behavior towards the company, belief the conduct is not in the best interest of the company, and knowledge or recklessness as to whether the conduct will cause serious loss to the company or benefit to a person who is not the company. ${ }^{86}$

There is no evidence to suggest that omitting the information was done in bad faith. Conversely, the Court of Appeal accepted that the directors honestly believed that the statements accurately reflected the relevant liquidity information relating to the company. $^{87}$

The prosecution would have to prove beyond reasonable doubt that that directors believed the omission would not be in the best interests of the company. However the reason the amended prospectus and investment statements were distributed were to raise funds to get through the period of suffering liquidity and to keep the company from becoming insolvent. The directors believed that the statements were true. ${ }^{88}$ They also believed they should not be overly pessimistic as to the liquidity concerns, as this could have "disastrous consequences" on existing investors. ${ }^{89}$ The reasons for the omission were for the continuation of Lombard and it would be extremely difficult for the prosecution to prove that the directors believed omitting the information was not in the best interests of the company with the amount of evidence that suggests the contrary.

\footnotetext{
${ }^{84}$ Walker and others, above $\mathrm{n} 42$, at [1403].

${ }^{85}$ Robb v Sojourner, above n 48.

${ }^{86}$ Supplementary Order Paper 2013 (249) Companies and Limited Partnerships Amendment Bill (344-2), cl 4.

${ }^{87}$ William Patrick Jeffries $v$, above $\mathrm{n} 2$, at [189].

${ }^{88}$ At [189].

${ }^{89}$ At [127].
} 
There is no evidence of the directors having knowledge that omitting the information would cause serious loss to the company or benefit someone that was not the company. Recklessness requires the subjective appreciation of a risk and the running of that risk which is deemed objectively unreasonable. ${ }^{90}$ For reasons stated in the FMC Bill analysis above, there must have been some subjective appreciation by the directors of a risk to the company by the omission. However it is unlikely that the prosecution would be able to prove the directors subjectively appreciated the risk that their conduct would cause serious loss to the company. ${ }^{91}$

Due to the prosecution likely not being able to prove the elements of the offence, the exclusion of the information would not result in criminal liability under this proposed change.

The Bill also criminalises elements of the reckless trading provision by amending s 380 of the Companies Act 1993. A director must not agree to or cause or allow the business of the company to be carried on in a manner that causes serious loss to the company's creditors, the director must know that a serious loss will be suffered as a result of business being carried on in that manner and the creditors that suffered the loss did not give prior consent to carrying on the business in that manner. ${ }^{92}$ Creditors will suffer 'serious losses' if a loss is of a kind more significant than a material loss. ${ }^{93}$ While clear that directors must consider the interests of existing creditors when insolvent or nearly insolvent, ${ }^{94}$ it has also been held that the duty may extend to interests of future or prospective creditors. $^{95}$

\footnotetext{
${ }^{90} R v$ Stephenson, above $\mathrm{n} 68$.

${ }^{91}$ Supplementary Order Paper 2013 (249) Companies and Limited Partnerships Amendment Bill (344-2), cl 4(c).

${ }^{92}$ Supplementary Order Paper 2013 (249) Companies and Limited Partnerships Amendment Bill (344-2), cl $4 \mathrm{AAB}$.

${ }^{93}$ Supplementary Order Paper 2013 (249) Companies and Limited Partnerships Amendment Bill (344-2), Explanatory note.

${ }^{94}$ Gray v Wilson [1998] 8 NZCLC 261,530.

${ }^{95}$ Fernyhough v Rankin Nominees Limited [1998] 8 NZCLC 261,623.
} 
In regards to the first element of the offence, the focus is not the directors' beliefs, but rather the manner in which a company's business is carried on. ${ }^{96}$ The manner in which Lombard was carried on was that directors relied upon loan managers' assurances as to liquidity. ${ }^{97}$ There was a sharp deterioration and constant downward trend in the company's cash position, a pattern of serious delays in the recovery of loan repayments and significant discrepancies between projected timing of repayments and actual payment. ${ }^{98}$ Here, the directors allowed the business to be conducted in a way that caused serious to their current creditors and prospective creditors. They allowed offer documents to be distributed to potential creditors, omitting information which should have been known to the directors and should have been told to the creditors. The company's liquidity was heading in a very concerning direction and not informing potential creditors of this caused them significant financial loss. The directors also failed to take a more intensive look into the loan exposures they had and merely relied on management, conducting the business in a way which caused substantial loss to existing creditors.

However the offence requires the directors know that a serious loss will be suffered by the company's creditors as a result of the business being carried on in such a manner. The prosecution would have to prove the Lombard directors knew the creditors would suffer losses from not including the liquidity information and by not taking a more intensive look into loan exposures. Nothing on the fact suggests that the Lombard directors knew this. Conversely, they believed the statements were true ${ }^{99}$ and made the statements to avoid losses to creditors. ${ }^{100}$ Arguably, they had no definite knowledge that creditors would suffer losses from their conduct, and in fact, thought their conduct would benefit the creditors. Because of this, the second element of the offence would likely be unsatisfied and the Lombard directors would not be found criminally liable for their omission under this proposed change.

\footnotetext{
${ }^{96}$ Mason v Lewis [2006] 3 NZLR 225 at [51].

${ }^{97}$ William Patrick Jeffries $v R$, above $\mathrm{n} 2$, at [64].

${ }^{98}$ At [170].

${ }^{99}$ At [189].

${ }^{100}$ At [127].
} 


\section{$V$ Current law vs. proposed changes - Discussion}

\section{A Securities Act 1978 and Financial Markets Conduct Bill}

\section{Knowledge}

Instead of being guilty for simply omitting information, the directors under the proposed changes in the FMC Bill must know that their omission will be materially detrimental for prospective investors. This would be dishonest conduct, with a director making the conscious choice to mislead potential investors, knowing they will be worse off because of it. It would be an abuse of the position the director holds, as a fiduciary. This was not the type of conduct which occurred in Jeffries. The directors were not acting dishonestly; they omitted information because they honestly believed the prospectus to be true. At the time the offer documents were distributed they believed that they would get through the period of tight liquidity. They omitted the information for what they saw as the best interests of the company, and in turn, the best interests of the investors. They made a business decision which turned out to be the wrong decision, and were held to be criminally liable because of it.

Strict criminal liability for honest behavior seems inherently wrong. Knowledge of acts or omissions having an adverse effect on potential investors is arguably the appropriate level to set the threshold for criminal liability. A director of a finance company has the potential to do great financial harm to people due to the position that they occupy. But directors should not be held criminally liable for merely taking risks with honest intentions. Criminal liability for finance directors should be reserved for acts which encompass dishonesty, with the director subjecting the interest of investors to their own illegitimate purposes.

The new standard set in the FMC Bill encompasses this idea, and the prospective change would mean that directors would have a better chance of being protected from criminal liability for acts or omissions done which are free of dishonesty, as seen by the likely result of Jeffries. 


\section{Recklessness}

The Bill also includes criminal liability for being reckless. Although this may appear a significant move from the present strict liability offence under s 58, this shift is less than it seems.

The defence to a charge under the current s 58 asks if the director had reasonable grounds to believe that the prospectus was true. ${ }^{101}$ The test for recklessness asks whether it was unreasonable to run that risk. ${ }^{102}$ Both tests bring an element of objectivity, being: was it unreasonable to believe it was true and was it unreasonable to run the risk. What this does is places the burden on the court to decide whether it was unreasonable. In Jeffries, the court said that relying on assurances and thinking that potential investors could trust the directors' judgment was unreasonable. ${ }^{103}$ This was accepted on the balance of probabilities. In regards to the potential change, it must be proved that running the risk was unreasonable beyond reasonable doubt. Although this standard is higher, the test is in effect the same as that to satisfy the s 58 defence. This begs the question of whether the reform serves any purpose by the inclusion of a reckless standard, if the test is in effect the same.

Recklessness is arguably not an appropriate level of fault for directors to be criminally liable for omissions in offer material. For recklessness, what is relevant is whether directors knew of the risk of the omission being materially adverse. In a commercial setting, risk is normal and will always exist. Running the risk needs to be unreasonable, but this in itself poses problems. What may be reasonable or unreasonable is circumstantial and no decisive test could be constructed to determine commercial reasonableness. Directors have the job of making the decisions, balancing financial factors and the duties they owe under various statutes and the court has said that this is a

\footnotetext{
${ }^{101}$ Securities Act 1978, s 58(4).

${ }^{102} R v$ Stephenson, above $\mathrm{n} 68$.

${ }^{103} R v$ Graham, above n 61, at [125]-[126].
} 
finely balanced exercise which it is the director's job to do. ${ }^{104}$ Yet the court is then expected to determine whether such a finely balanced decision was reasonable or not. It may be perfectly reasonable for directors in risky situations to decide one way or the other, and placing this decision under objective inquiry can blur the line between conscious wrongdoing and negligence, misjudgment and other examples of simply getting it wrong. ${ }^{105}$ Although not likely, it would be possible for the Lombard directors to be found guilty if the court could prove beyond reasonable doubt that it was unreasonable to run the risk, a conclusion that seems to undermine the purpose of the proposed legislative change.

\section{B Companies and Limited Partnerships Amendment Bill}

\section{$1 \quad$ Section 131}

The criminal offence relating to a breach of the duty in s 131, to act in good faith and in the best interests of the company, would unlikely be breached in respect to the Lombard directors. This is due to the fact that there was likely no dishonest behavior or subjective appreciation that loss would result from their conduct.

Such a result would enhance the purpose the FMC Bill is trying to establish, being criminal liability for intentionally dishonest conduct. The need for bad faith behavior means only dishonest conduct will be criminal, further strengthened by subjective appreciation that conduct was not in the best interests of the company and would cause serious loss to the company. The offence steers away for objectively imposed criminal liability and seems to promote the idea that dishonesty is what is relevant to be able to find a company director liable. It sits comfortably with only criminalising the most egregious conduct.

\footnotetext{
${ }^{104}$ William Patrick Jeffries $v$, above $\mathrm{n} 2$, at [172].

${ }^{105}$ Chapman Tripp "Submission to the Commerce Committee on the Financial Markets Conduct Bill 2011" at [126.1].
} 
The Court of Appeal stated obiter that the obligation to ensure disclosure documents are true overrides the duty the directors owe to the company to act in the best interests where the duties conflict. ${ }^{106}$ By adhering to the duty to ensure disclosure documents are true, serious loss to the company can occur, for example overstating liquidity concerns could result in low investment and cause the premature demise of a company. While this means that directors will at times act in a manner that is arguably not in the best interests of the company and where they potentially know their conduct will cause serious loss, adhering to disclosure requirements correctly cannot be said to be bad faith behavior towards the company. Where the two duties conflict a breach of the duty to act in the best interests of the company may occur. However no criminal liability would occur under the CLPA Bill from these conflicting duties due to the need to have bad faith behavior.

The proposed amendment to s 131 would criminalise dishonest behavior, as directors acting in bad faith for personal benefit would be guilty of the offence. But this type of offence already exists, and there is arguably no gap in which the criminalisation is filling. ${ }^{107}$ This is evident in situations such as in Tallentire. Section $220{ }^{108}$ holds directors guilty when they know they are breaching the investor's interest, and act in favor of their own interests. This case is just one example of current law already holding directors criminally accountable for their known breaches of the trust position in which they hold. Other statutory sections such as obtaining a benefit or causing loss by deception, ${ }^{109}$ making false statements by a promoter, ${ }^{110}$ fraudulent use or destruction of property, ${ }^{111}$ falsify records with intent to defraud, ${ }^{112}$ and knowingly carry on business with intent to defraud creditors ${ }^{113}$ are just a few examples of current criminal charges that already exist to do the job that the criminalisation of s 131 aims to do. It begs the question whether

\footnotetext{
${ }^{106}$ William Patrick Jeffries $v$, above $\mathrm{n} 2$, at [172].

${ }^{107}$ Chapman Tripp "Submission to the Commerce Committee on the Companies and Limited Partnerships Amendment Bill 2011" at [14]-[18].

${ }^{108}$ Crimes Act 1991, s 220.

${ }^{109}$ Crimes Act 1991, s 240.

${ }^{110}$ Crimes Act 1991, s 242.

${ }^{111}$ Companies Act 1993, s 378.

${ }^{112}$ Companies Act1993, s 379.

${ }^{113}$ Companies Act 1993, s 380.
} 
such a proposed change will have any impact of the current criminal regime at all, or whether it will merely complicate the area of law which seems to be, with Tallentire as a prime example, doing its intended job already.

\section{Section 380}

The amendment to s 380 of the Companies Act $1993^{114}$ is a lot less concerning than the originally proposed criminalisation of $\mathrm{s} 135$, a section which has been criticised by virtually every commentator who has discussed it. ${ }^{115}$

However the first part of the offence retains some issues. By looking specifically at how the company conducts itself, it remains open that this part of the offence can be satisfied with less than dishonest behavior. A director who negligently allows the company to be carried on in a way which causes loss to creditors will satisfy the first part of the offence. This issue is however rectified by the second part of the offence; due to the director needing to have knowledge that the creditors will suffer serious loss. This subjective inquiry means that negligent and reckless conduct will not impose criminal liability under this section, reserving it only for intentionally dishonest behavior. This again fits with the idea of only criminalising the most egregious conduct.

Another issue with the offence is that it requires serious loss by the creditors to actually occur. ${ }^{116}$ What this means is that the section cannot be used as a preemptive attempt to stop a business being carried on in a way likely to cause loss to creditors. Whilst replacing "substantial risk" 117 with actual serious loss is arguably a change for the better, what this means is the criminal offence is now more of a punishment for directors rather

\footnotetext{
${ }^{114}$ Supplementary Order Paper 2013 (249) Companies and Limited Partnerships Amendment Bill (344-2), cl 4AAB.

115 South Pacific Shipping Limited (in Liquidation), Re; Traveller \& Anor v Löwer, above n 73, at [127][128].

${ }^{116}$ Supplementary Order Paper 2013 (249) Companies and Limited Partnerships Amendment Bill (344-2), cl $4 \mathrm{AAB}(2)$.

${ }^{117}$ Companies and Limited Partnerships Amendment Bill (344-2), cl 4.
} 
than being a protection for creditors. With the only sanctions under this offence being imprisonment and a fine, ${ }^{118}$ the creditors themselves are limited as to the effectiveness of this proposed change.

The intention behind the criminalisation of these directors' duties was that there was no public enforceability of the duties. ${ }^{119}$ The enforcement that existed was by the company itself and by way of derivative actions of shareholders. ${ }^{120}$ However, New Zealand now has the Financial Markets Authority (FMA) that can take actions against a company that issues securities to the public, ${ }^{121}$ specifically for a breach of duty. ${ }^{122}$ If public enforceability was the objective of the criminalisation of director duties, and this has been done by the creation of the FMA, then the question must be asked if the criminalisation of these duties is necessary at all. Australia has criminalised provisions similar to ss 131 and $135,{ }^{123}$ however the type of breaches that attract the use of those sanctions are where directors are knowingly and intentionally dishonest, ${ }^{124}$ rather than merely taking risks.

\section{Civil liability regime}

\section{A Civil liability vs. criminal liability}

Criminal law inherently risks the autonomy of the individual. Over-using such a mechanism can be extremely risky to society. Deterrence and accountability should arguably be done in a way that is the least restrictive. This is what the FMC Bill aims to do, moving away from the strict criminal offences to a regime which places emphasis on civil liability, reserving criminal charges for the most egregious types of behavior.

\footnotetext{
${ }^{118}$ Companies Act 1993, s 373(4)(f).

119 At [209].

${ }^{120}$ At [202].

${ }^{121}$ Financial Markets Authority Act 2011, s 34(1).

${ }^{122}$ Financial Markets Authority Act 2011, s 34(2)(b).

${ }^{123}$ Corporations Act 2001 (Cth), s 184.

124 Susan Watson and Rebecca Hirsch "Empty Heads, Pure Hearts: The Unintended Consequences of the Criminalisation of Directors’ Duties" (2011) 17 NZBLQ 97 at 105-106.
} 
Criminal law should be certain; however the proposed changes do not sit well with this idea. The recklessness element of $\mathrm{cl} 488^{125}$ places criminal liability at the discretion of the courts based on what they deem to be an 'unreasonable risk.' Furthermore, the requirement of actual loss in the amendment of s $380^{126}$ places severe limits on the offence's usefulness. Such issues within the proposed changes beg the question whether criminal sanctions are appropriate at all.

The civil liability regime within the FMC Bill is vast. The court has wide powers in breaches of civil liability sections, such as ordering compensation, pecuniary penalties and making banning orders against directors. ${ }^{127}$ Such liability should act as a deterrent and sufficient penalty for breaches which were either innocent or due to the director's negligence, imposed upon a director as a deemed contravention. ${ }^{128}$ This point is illustrated through the likely result of Jeffries, where the less than dishonest conduct would have brought about the consequence of a contravention of $\mathrm{cl} 65^{129}$, bringing about civil liability. Such liability, without attaching the stigma of being a 'criminal' would still deter and penalise actions such as theirs. The regime provides a sensible middle ground and is arguably more appropriate than across-the-board criminal sanctions. As the orders are more flexible, the actual harm done can be compensated more efficiently, better taking victims' rights into account and there are a range of defences available.

Academics argue as to whether civil or criminal penalties lead to more effective and efficient enforcement of obligations that directors owe, with some commentators questioning whether civil penalty proceedings actually prevail over criminal proceedings. ${ }^{130}$ Of course in cases of dishonesty, criminal sanctions will be appropriate, but in more questionable cases, such as $R v$ Jeffries, it remains open to argument that a

\footnotetext{
${ }^{125}$ Financial Markets Conduct Bill (342-2), cl 488.

${ }^{126}$ Supplementary Order Paper 2013 (249) Companies and Limited Partnerships Amendment Bill (344-2), cl $4 \mathrm{AAB}$.

${ }^{127}$ Financial Markets Conduct Bill (342-2), pt 7.

${ }^{128}$ Financial Markets Conduct Bill (342-2), cl 509A.

${ }^{129}$ Financial Markets Conduct Bill (342-2), cl 65.

${ }^{130}$ Watson and Hirsch, above n 124, at 118.
} 
civil liability regime is in fact a better mechanism to deal with and deter conduct of that type.

\section{B Problems within the civil liability regime}

The civil liability regime of the FMC Bill does have some issues. Liability arises by contravening a civil liability provision, defined in the Bill. ${ }^{131}$ Civil liability orders can be ordered for a contravention or for involvement in a contravention, ${ }^{132}$ which is also defined by the Bill. ${ }^{133}$ This means that all others 'involved' in the contravention can be held liable and risk the very broad powers of the court's civil liability orders. An employee, acting under direction, or a professional advisor, acting under a contractual obligation potentially can be held liable for the acts. ${ }^{134}$ Such a broad meaning can have unwanted and unnecessary consequences, such as liability for employees for innocent acts they are bound to do. The New Zealand Law Society argues it also has the potential to undermine the relationships between issuers and their advisors and create an increasingly inefficient securities market. ${ }^{135}$

Further problems are procedural issues in the context of civil proceedings, which arise from the fact that civil penalties are mixture of both civil remedies and criminal sanctions. ${ }^{136}$ Civil penalty proceedings within the Bill use the standard of proof of balance of probabilities. ${ }^{137}$ However this standard may be applied flexibly. ${ }^{138}$ The more serious the breach, the more evidence will be required before the standard is met, which

\footnotetext{
${ }^{131}$ Financial Markets Conduct Bill (342-2), cl 467.

${ }^{132}$ Financial Markets Conduct Bill (342-2), cl 466.

${ }^{133}$ Financial Markets Conduct Bill (342-2), cl 509.

${ }^{134}$ NZ Law Society "Submission to Commerce Committee on the Financial Markets Conduct Bill 2011" at [29].

135 At [30].

${ }^{136}$ Watson and Hirsch, above n 124 , at 118.

${ }^{137}$ Financial Markets Conduct Bill (342-2), cl 487.

${ }^{138}$ Honda New Zealand Ltd v New Zealand Boilermakers' etc Union [1991] 1 NZLR 392 (CA). Z v Dental Complaints Assessment Committee [2008] NZSC 55, [2009] 1 NZLR 1 at [102].
} 
potentially elevates the civil standard of proof in civil liability proceedings. ${ }^{139}$ This means that the civil liability regime, potentially aimed at holding directors who are not dishonest, but still have done major harm, could shift to one which more looks like a criminal liability regime. ${ }^{140}$ Such a procedural rule could undermine the purpose of having a civil liability system and all the benefits that result because of it.

\section{Conclusion}

The current criminal liability regime for finance company directors is unsatisfactory. Guilty verdicts can arise from taking commercially questionable but honestly intentioned decisions, which if the coin landed on heads instead of tails, would have brought about no action at all. The FMC Bill looks to better protect directors. The introduction of mental elements which need to be satisfied prima facie looks to solve the problems associated with the current strict liability offence. However, the inclusion of the recklessness standard means criminality is to some extent at the opinion of the courts. An interpreter of law becomes a legislator, deciding what is and isn't criminal based on the courts view of what is commercially appropriate. Such a finely balanced inquiry in the past has been avoided by Commonwealth courts, ${ }^{141}$ and would serve as New Zealand's mandate in regards to finance company directors.

The criminalisation of directors' duties seems to serve a more appropriate purpose. It criminalises conduct which is intentionally dishonest and better fits within the idea of reserving criminal sanctions for only the most egregious conduct. However the need for such criminalisation is questionable, with criminal sanctions already in place to cover the supposed 'gap' the CLPA Bill is attempting to fill.

Dishonest conduct, for self-serving purposes and at the expense of innocent and trusting investors should not be tolerated in society and deserves criminal ramifications. But for

\footnotetext{
${ }^{139}$ Watson and Hirsch, above n 124, at 119.

${ }^{140}$ Law Commission "Civil Pecuniary Penalties - Issues Paper 33"

$<$ http://ip33.publications.lawcom.govt.nz/Chapter+6+-+The+critical+issues/Standard+of+proof $>$ at [6.30].

${ }^{141}$ Harlowe's Nomiees Pty Woodside (Lakes Entrace) Oil Co (1968) 121 CLR 483, 493 (HCA).
} 
conduct which occupies the grey area, should honest or legitimate conduct have the same consequences? Parliament looks to answer such a question, but seems undecided, with Bills progressing through Parliament pulling liability toward both sides of the argument. The passing of both Bills would leave the criminal liability regime in a confused state, with potential over-charging and uncertainty issues. For a directional change aimed at "deterring dishonest conduct", ${ }^{142}$ the actual results of the proposed changes do not completely conform to this.

\section{Word count}

The text of this paper (excluding table of contents, footnotes, and bibliography) comprises approximately 7933 words.

$\overline{142}$ Review of Securities Law: Cabinet Paper (Cabinet Economic Growth and Infrastructure Committee, February 2011) at [211]. 


\section{Bibliography}

\section{A Cases}

$1 \quad$ New Zealand

Fernyhough v Rankin Nominees Limited [1998] 8 NZCLC 261,623.

Gray v Wilson [1998] 8 NZCLC 261,530.

Honda New Zealand Ltd v New Zealand Boilermakers' etc Union [1991] 1 NZLR 392 (CA).

Mason v Lewis [2006] 3 NZLR 225.

$R v$ Douglas [2012] NZHC 1746.

Rv Graham [2012] NZHC 265.

$R v$ Tipple CA217/05, 22 December 2005.

$R v$ Stephenson [1979] QB 695 (CA).

Robb v Sojourner [2007] NZCA 493.

South Pacific Shipping Limited (in Liquidation), Re; Traveller \& Anor v Löwer (2004) 9 NZCLC 263,570.

Tallentire $v R$ [2012] NZCA 610, [2013] 1 NZLR 548.

William Patrick Jeffries v R [2013] NZCA 188.

Zv Dental Complaints Assessment Committee [2008] NZSC 55, [2009] 1 NZLR 1.

$2 \quad$ Australia

Harlowe's Nomiees Pty Woodside (Lakes Entrace) Oil Co (1968) 121 CLR 483, 493 (HCA). 


\section{B Legislation}

$1 \quad$ New Zealand

I Statutes

Companies Act 1993.

Crimes Act 1961.

Financial Markets Authority Act 2011.

Securities Act 1978.

II Bills

Companies and Limited Partnerships Amendment Bill (344-2).

Financial Markets Conduct Bill 2011 (342-2).

III Supplementary Order Papers

Supplementary Order Paper 2013 (249) Companies and Limited Partnerships Amendment Bill (344-2).

2 Australia

Corporations Act 2001.

\section{Books and Chapters in Books}

J Farrar and others Company and Securities Law in New Zealand (Thompson Brookers, Wellington, 2008).

G Walker and others Commercial Applications of Company Law in New Zealand (3rd ed, CCH, Auckland, 2009). 


\section{Journal Articles}

Susan Watson and Rebecca Hirsch "Empty Heads, Pure Hearts: The Unintended Consequences of the Criminalisation of Directors' Duties” (2011) 17 NZBLQ 97.

\section{E Parliamentary and Government Materials}

Chapman Tripp "Submission to the Commerce Committee on the Financial Markets Conduct Bill 2011".

NZ Law Society "Submission to Commerce Committee on the Financial Markets Conduct Bill 2011".

Review of Securities Law: Cabinet Paper (Cabinet Economic Growth and Infrastructure Committee, February 2011).

\section{G Internet Resources}

David Farrar "The Lombard appeal to the Supreme Court" (4 July 2013) KiwiBlog <www.kiwiblog.co.nz/wp-content/uploads/2013/07/Lombard-Appln-Leave-to-AppealSC-2-July-2013.pdf>.

John McSoriley “Bills Digest No 1963” (03 April 2012) New Zealand Parliament $<$ http:/www.parliament.nz/en-nz/pb/legislation/bills/digests/50PLLaw19631/financialmarkets-conduct-bill-2011-bills-digest-no-1963>.

Law Commission “Civil Pecuniary Penalties - Issues Paper 33”

$<$ http://ip33.publications.lawcom.govt.nz/Chapter+6+-

+ The + critical + issues $/$ Standard + of + proof $>$ 
